\title{
Études/Inuit/Studies
}

\section{Whose agenda is it? Regulating health research ethics in Labrador \\ Whose agenda is it? Regulating health research ethics in Labrador}

\section{Fern Brunger et Julie Bull}

Volume 35, numéro 1-2, 2011

URI : https://id.erudit.org/iderudit/1012838ar

DOI : https://doi.org/10.7202/1012838ar

Aller au sommaire du numéro

Éditeur(s)

Association Inuksiutiit Katimajiit Inc.

Centre interuniversitaire d'études et de recherches autochtones (CIÉRA)

ISSN

0701-1008 (imprimé)

1708-5268 (numérique)

Découvrir la revue

Citer cet article

Brunger, F. \& Bull, J. (2011). Whose agenda is it? Regulating health research ethics in Labrador. Études/Inuit/Studies, 35(1-2), 127-142.

https://doi.org/10.7202/1012838ar
Résumé de l'article

Au Labrador, les NunatuKavut (auparavant appelés les Métis Inuit du Labrador) ont commencé à établir un rigoureux processus communautaire d'évaluation de la recherche. Nous avons mené une étude avec des gestionnaires et des travailleurs en santé de la communauté nunatukavut du Labrador et au-delà, en leur demandant ce qui devrait être mis en valeur au cours d'une évaluation communautaire. Nous avons également cherché à identifier si, et comment, une évaluation communautaire devait être distincte des évaluations «institutionnelles» d'éthique de la recherche qui restent l'apanage des autorités provinciales de Terre-Neuve et du Labrador en matière de recherche en santé. Dans cet article, nous présentons nos résultats dans le but de fournir des stratégies et une orientation aux chercheurs, aux comités d'éthique de la recherche et aux communautés autochtones ayant affaire à un double niveau d'évaluations éthiques. Nous plaidons pour la création et l'utilisation d'une dénomination cohérente pour l'évaluation communautaire de la recherche («comité communautaire d'évaluation de la recherche») qui soit distinct des comités d'éthique de la recherche. Nous suggérons quelques pistes pour que les rôles et les responsabilités du comité communautaire d'évaluation de la recherche soient distincts ainsi que clairement compris et délimités. Notre objectif est de promouvoir une forme d'évaluation communautaire de la recherche qui soit différente des évaluations «éthiques» des comités d'éthique de la recherche, et qui ait explicitement pour rôle d'assister la recherche dans un contexte où se perpétuent le colonialisme, l'assimilation et l'exotisme. 


\title{
Whose agenda is it? Regulating health research ethics in Labrador
}

\author{
Fern Brunger*, Julie Bull**
}

Résumé: L'agenda de qui? Réglementer l'éthique dans la recherche sur la santé au Labrador

Au Labrador, les NunatuKavut (auparavant appelés les Métis Inuit du Labrador) ont commencé à établir un rigoureux processus communautaire d'évaluation de la recherche. Nous avons mené une étude avec des gestionnaires et des travailleurs en santé de la communauté nunatukavut du Labrador et au-delà, en leur demandant ce qui devrait être mis en valeur au cours d'une évaluation communautaire. Nous avons également cherché à identifier si, et comment, une évaluation communautaire devait être distincte des évaluations «institutionnelles» d'éthique de la recherche qui restent l'apanage des autorités provinciales de Terre-Neuve et du Labrador en matière de recherche en santé. Dans cet article, nous présentons nos résultats dans le but de fournir des stratégies et une orientation aux chercheurs, aux comités d'éthique de la recherche et aux communautés autochtones ayant affaire à un double niveau d'évaluations éthiques. Nous plaidons pour la création et l'utilisation d'une dénomination cohérente pour l'évaluation communautaire de la recherche («comité communautaire d'évaluation de la recherche») qui soit distinct des comités d'éthique de la recherche. Nous suggérons quelques pistes pour que les rôles et les responsabilités du comité communautaire d'évaluation de la recherche soient distincts ainsi que clairement compris et délimités. Notre objectif est de promouvoir une forme d'évaluation communautaire de la recherche qui soit différente des évaluations «éthiques» des comités d'éthique de la recherche, et qui ait explicitement pour rôle d'assister la recherche dans un contexte où se perpétuent le colonialisme, l'assimilation et l'exotisme.

\begin{abstract}
Whose agenda is it? Regulating health research ethics in Labrador
In Labrador, the NunatuKavut (formerly Labrador Inuit Métis) have begun to introduce a rigorous community-based research review process. We conducted a study with leaders and health care workers in and beyond the NunatuKavut community of Labrador, asking them what should be emphasised in a community review. We also sought to identify whether and how community review should be distinct from the centralised, "institutional" research ethics review that would be the mandate of Newfoundland and Labrador's impending provincial health research authority. In this article we report on our findings with the aim of providing strategies and direction for researchers, research ethics boards, and Aboriginal communities dealing with dual-level ethics review. We argue for the adoption and use of a consistent label for community review of research ("Community Research Review Committee") as distinct from research ethics
\end{abstract}

\footnotetext{
* Faculty of Medicine, Memorial University, 300 Prince Philip Drive, St. John's, Newfoundland, A1B 3V6, Canada, fbrunger@mun.ca

** Department of Interdisciplinary Studies, University of New Brunswick, 100 Tucker Park Road, P.O. Box 5050, Saint John, New Brunswick, E2L 4L5, Canada. julierbull@gmail.com
}

ÉTUDES/INUIT/STUDIES, 2011, 35(1-2): 127-142 
boards. We provide suggestions for the development of separate roles and responsibilities for community review of research to ensure that its tasks are clearly understood and delineated. Our objective is to promote a form of community research review, distinct from the "ethics" review of research ethics boards, that explicitly attends to research in the context of ongoing colonialism, assimilation, and exoticism.

\section{Introduction}

The province of Newfoundland and Labrador has moved to a legislated provincewide health research ethics review system. Under the provincial Health Research Ethics Authority (HREA), an ethics board (HREB) reviews all health research ${ }^{1}$ and requires community consent for research involving Aboriginal communities, as set forth in the Tri-Council Policy Statement (TCPS2) guidelines (CIHR et al. 2010). Therefore, since proclamation of the HREA in July 2011, all such research-whether publicly or privately funded and whether university, government, or community-initiated-must undergo two levels of review: 1) review by the provincial HREB and 2) review and acceptance by the Aboriginal communities involved in or affected by the research. ${ }^{2}$

In Labrador, the NunatuKavut have begun the process of introducing a rigorous community-based research review process. In 2007, we $\mathrm{w}^{3}$ conducted the pilot study "Interpreting the CIHR Guidelines for Health Research Involving Aboriginal Peoples in community-based research" with community leaders and health care workers in and beyond the NunatuKavut community of Labrador, asking them what should be emphasised in a community review. As part of that inquiry, we also sought to identify whether and how a community review should be distinct from the centralised, "institutional" research ethics review that would be the mandate of the new provincial HREB.

In this paper we report on our findings with the aim of providing strategies and direction for researchers, REBs, and Aboriginal communities dealing with dual-level ethics review. We argue for the adoption and use of a consistent label for community review, i.e. a Community Research Review Committee (CRRC), as distinct from research ethics boards (REBs). We suggest giving the community clearly understood

1 See Government of Newfoundland and Labrador (2007).

2 Note that aside from the TCPS2 guidelines (CIHR et al. 2010), HREB policy requires that research involving Aboriginal peoples must follow the CIHR's (2008) Guidelines for Health Research Involving Aboriginal Peoples and will not grant ethics approval until community acceptance is obtained.

3 The study was funded by the Atlantic Aboriginal Health Research Program. Fern Brunger was the principal investigator and Julie Bull the co-investigator. 
and delineated roles and responsibilities that are separate from those of the research ethics board. Our objective is to promote a distinct form of community review that explicitly attends to research in the context of ongoing colonialism, assimilation, and exoticism.

\section{The complexities of community consent in Labrador}

This research was the outcome of a workshop on Community Health Research in Labrador: Listening, Learning, and Working Together (2006). The workshop brought together university-based researchers, health workers, and community members to identify priorities for health research. They identified two priorities: research ethics and governance of research involving Aboriginal People in Labrador. Brunger and Bull then began working with community members to design a project. The Labrador Aboriginal Health Research Committee (LARHC), formed in the wake of the 2006 workshop, assumed the role of community advisory team to the researchers and provided the avenue for research design and process. It was comprised of individuals who wished to advance the governance of Aboriginal health research in Labrador. They included representatives from the NunatuKavut (then the Labrador Métis Nation), Nunatsiavut Government, Sheshatshiu and Mushuau Innu Health Commissions, Health Canada, Labrador-Grenfell Regional Health Authority, Rural Secretariat-Provincial Department, Atlantic Aboriginal Health Research Program, and the Labrador InstituteMUN extension. Mutually agreed upon documentation and research methods were to be used.

The community advisory committee identified key informants on the basis of their role in health research, involvement with the community, and/or interest in governance of research involving Aboriginal peoples. These informants included, but were not limited to, individuals from the Inuit, Innu and NunatuKavut communities who selfidentified or were identified by others as community leaders who had a personal or professional mandate to advocate on behalf of the community for ethical research, as well as members of LAHRC. In total, 18 individuals were interviewed.

\section{"Community" in the Labrador context}

Labrador is on the Canadian mainland, northwest of the island of Newfoundland and adjacent to the province of Quebec, with a population of approximately 27,000 (Statistics Canada 2006) including Innu, Inuit, NunatuKavut (Inuit-Métis), and nonAboriginal people. Within Labrador, there are multiple political, social, and geographic centres of identity and belonging. These centres include the Aboriginal political organisations (NunatuKavut, Nunatsiavut, and Labrador Innu Nation) as well as the various non-Aboriginal politically defined communities. The three Aboriginal political organisations (which are also cultural and social entities) represent individuals dispersed over multiple, often geographically remote, municipal communities. 
These three organisations must vie for access to federal program and project monies. As a result, resources and power are unequally distributed among all three, as well as within each of them. Concomitantly, they have a cohesiveness that comes with a broader pan-Canadian identity. The Labrador Innu, Inuit, and NunatuKavut are affiliates of national organisations: the Assembly of First Nations, Inuit Tapiriit Kanatami, and the Congress of Aboriginal People, among others.

Figure 1 illustrates the complexity of the various political and cultural nested circles of belonging in Labrador. Multiple centres overlap within these concentric circles; each centre has a different political structure, economic situation, geographic dispersion, and cultural identity. For any given set of overlapping centres, there is always at least one bigger centre that encompasses the set and a smaller centre that marks diversity from the whole.

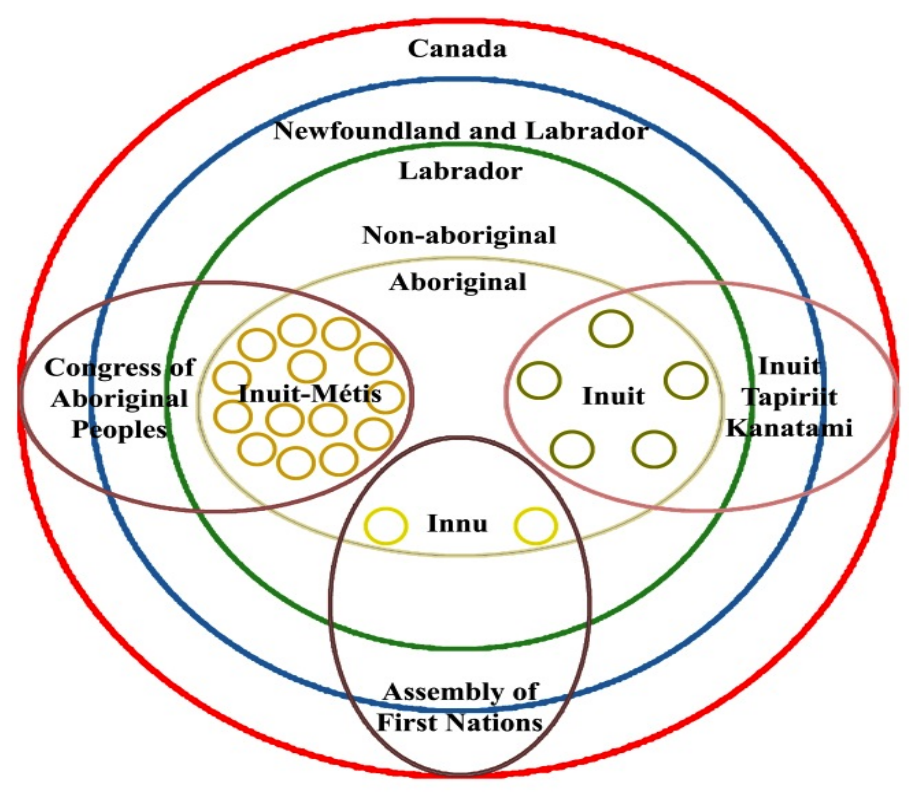

Figure 1. Nested concentric circles of belonging in Labrador.

The Innu, Inuit, and NunatuKavut communities of Labrador were all negatively impacted by a series of political and economic events from the 1940s to the 1970s and into the present day. Most notably, mining towns were built in Labrador City, Wabush, and Schefferville, and a military base was created at Goose Bay during World War II. The Churchill Falls hydroelectric development in the 1970s resulted in thousands of square kilometres of land being flooded, thus destroying many traditional hunting and burial grounds. These and other economic developments brought increasing numbers of non-Aboriginal people into once predominantly Aboriginal regions. Provincial hunting regulations were changed to reflect the shifting social, economic, and cultural contexts, further altering the lifestyle of Aboriginal peoples. Provincial authorities undertook resettlement with a view to improving the social and economic welfare of Aboriginal peoples. Resettlement, however, disrupted the economic, social, and political structures of communities, thus creating substantial negative long-lasting effects and contributing 
to many of the health and social challenges facing Labrador Aboriginal peoples today (Bull 2008).

\section{Resistance to research}

Indigenous peoples have endured various inquests and inquiries about their health, education, culture, and traditions (Alfred and Corntassel 2005; Battiste 2000; Smith 1999). Such efforts have primarily been conducted under government and academic programs and have rarely included members of the Aboriginal communities in the decision-making process. Over time, resistance has developed among Aboriginal peoples (e.g., Humphrey 2007). Perceived exploitation in research, research fatigue, and past and present relationships with governments have influenced the ways the key stakeholders understand ethics and research. At the time of this writing, the NunatuKavut are strongly opposed to the proposed hydroelectric project at Muskrat Falls on Labrador's Churchill River. It is clear to us, from our conversations with community members, that such resistance is an effect, and not merely a cause, of the way in which academic and government research is perceived. Their words - "We are sick of being studied to death" - echo the work of Linda Tuhiwai Smith (1999), a Maori scholar who emphasises the need for decolonisation in all aspects of research, including the ethics review process.

\section{Priorities in the review of health research}

Our informants identified several community concerns about research: 1) benefit sharing, particularly in terms of immediacy and applicability to community well-being (rather than individual health); 2) dissemination, with emphasis on how to avoid reporting of research results in a way that essentialises or stigmatises a community; and 3) community autonomy in setting priorities and an agenda for health research within the community. This cluster of interrelated concerns was understood and discussed as being inextricably connected to the context of ongoing colonisation, assimilation, and exoticism.

\section{The Meaning of "Benefit"}

We need to make sure that the research that's taking place [is] on topics that are going to be beneficial to us and not only to the researcher to get their master's degree $\left(\mathrm{NG}^{4} 2\right)$.

Despite the large volume of research in their communities, the Labrador Innu, Inuit, and NunatuKavut informants were concerned that research does not always provide their people with tangible benefits. Health research may assist policy makers and health care workers, with individuals within a community receiving little in the way of "felt" or immediate benefit.

4 NG refers to a member of the Nunatsiavut Inuit community. 
I think [community members] need to understand about the benefits of research, and that research doesn't happen in a, you know, just an altruistic way-that [researchers] are doing it for their own advancement. And I don't mean that in a selfish way but, if you want an academic career, you have to go and research something. And so you do it partly for that, partly for the genuine, intellectual curiosity of it, and possibly advancing the community, although I wouldn't think that researchers are interested in not benefiting the community; but, if they're not from that community, then they're probably more objective about it. They just want to find out the answers to something. Where[as] communities have a big stake in saying, "what's in it for us if we're going to help you?" Those are not, they're not mutually exclusive but they're not the same objectives. So I think communities need to understand who benefits from research and how can everyone benefit, and can we cut some slack to people to say, okay, you need to satisfy your requirements. We want you to satisfy ours as well (LAHRC ${ }^{5}$ 2).

The informants offered examples of benefit sharing: financial or other direct remuneration to participants or to a community cause; clinical outcomes for individuals; evidence to support a local initiative to secure program funds; employment for research assistants; and workshops or training sessions in the community for capacity building. Financial incentives for individuals to participate are a source of frustration for community members, as there is little consistency between projects, and the inconsistency increases the potential for coercion:

Are you paying them for their time; are you paying them for their expertise- those are two different things - or are you paying them because other people are doing it and because it's the ethical thing? Are you paying them so it doesn't look like they're being exploited? Are you paying them because it's the quickest way to get information? (LAHRC 2).

Community members particularly noted that researchers should, at the very least, return results of their research to the community as a kind of benefit for participation.

I can think of an example of a university that came in and promised that they would, in fact, come back to the community and would give information [...] and it had to do with [describes research]. [A]t this end [we] helped out: we went out to the communities, did the interviews, collected the data [...] and then sent it back to the university. [We didn't hear back from the] principal [investigator] and [the community liaison] didn't know what happened to the research and whatnot. And then I read in the [...] Canadian Geographic, some of the results of the research project (LAHRC 1).

Because of this history, community members are increasingly aware of the importance of protecting traditional knowledge in research.

[There were] researchers coming through the hospital and cutting [and collecting] people's hair and [collecting] blood samples and going up the coast and doing the same thing, and nobody is really sure what they're doing or why they're doing it and, you know, hiring guides to take them to [a community] and stuff like that by boat, and they really have no idea of what the

5 LAHRC are members of the Labrador Aboriginal Health Research Committee, who may belong to the Nunatsiavut, Innu, or NunatuKavut communities but, for the purposes of this research, are prioritising their roles as health services worker or administrator. 
purpose of their study was. You know, brought them for a boil-up ${ }^{6}$ and all of this stuff. They never did speak about the study. They just [...] you know, enjoyed the Labrador experience and took what they needed and left (NG3).

This concern is in keeping with the CIHR's (2008) Guidelines for Health Research. As Kaufert et al. (2004: 25) wrote in their background research for that group, "[...] research should focus on locally relevant problems, or ensure that there be a commitment to community-based capacity building and the generation of local knowledge."

\section{Research exhaustion}

A common concern was research fatigue. As one participant put it, "Don't they know everything there is to know about us by now?" This was presented to us as a dilemma: on the one hand, communities need and want health research in their communities; on the other, the same individuals are being asked the same questions by multiple researchers from different projects. Individuals are feeling over-researched, while at the same time communities need to increase research. Burnout and boredom from being asked the same questions have reduced interest in further health research. There is growing disinterest in new research projects that have no apparent immediate or tangible benefit to community members. A key recommendation made to us was to have a central database (such as a research registry) that can provide researchers with the sort of information they recurrently need, thereby saving them and others time.

If this information was available here, it could save someone a lot of work if they didn't have to duplicate and community members would no longer feel like their information is falling on deaf ears $\left(\operatorname{LMN}^{7} 1\right)$.

\section{Dissemination: Homogenisation, exoticisation, ${ }^{8}$ and misrepresentation}

Homogenisation, exoticisation, and misrepresentation are an interrelated cluster of historical contexts that shape the meaning of "ethical" research and define contemporary strategies for ownership, control, access, and protection. Researchers sometimes fail to appreciate or acknowledge the diversity among and within Aboriginal communities (see Cunningham 2000). Participants reported, for instance, that research findings from one Inuit community have sometimes been erroneously extrapolated to all other Inuit communities. Participants emphasised that cultural norms and values are

6 A boil-up is a brew of tea and a snack taken outdoors or at a cabin in the woods. It is an impromptu gathering, often a break from work or a long walk.

7 Labrador Métis Nation, now the NunatuKavut Community Council.

8 We use the concept of "exoticisation," i.e. the representation of something as exotic, the process of representing Aboriginal peoples in ways that emphasise their difference from the non-Aboriginal researchers, primarily in terms of romanticising the culture and emphasising primitiveness (following Said's [1978] observations about the "othering" of the East by the West). 
important in research design and method but are also highly problematic if they lead to assumptions about similarities — or differences—-between groups.

There could be three, four, five different research groups [...] going through coastal Labrador asking the same questions [...] but also not having any knowledge of how these groups are different from each other or if they're from the same group (NG 3).

In some cases it may be legitimate to generalise specific research results to all Aboriginal peoples (First Nations, Inuit, and NunatuKavut), but in other cases the result may be misrepresentation of specific communities. Participants' comments were in keeping with the report by the Pauktuutit Inuit Women's Association (Bird 2002), which showed that researchers often have a simplistic view of the complex world of Aboriginal peoples. They may thus misrepresent or even distort the results of their research. Importantly, respondents directly linked misrepresentation to their history of colonisation, and in particular the explicit attempts at cultural assimilation. There was concern about a common misconception that "all Aboriginal peoples are the same."

A related concern was that research results might stigmatise a particular cultural, political, or geographic community through insensitive dissemination.

The media bothers me because you can take data that in and of itself is data, but you can put a spin on it. Yeah, we've had lots of kids in Labrador diagnosed with FAS $^{9}$; but should you take that and use it to go around saying that we have all these, you know, alcoholic communities and horrible [...] you know, you can turn into something very, very, very negative to the community that way, instead of using that data to put in the supports that a community might need. You might use it to besmirch the community $[\ldots]$ you know, to turn it into a news story to really make one community look ugly. I've seen that done and I've seen the media do it. And that's a [...] that might not have been the fault of the researcher at all. There's risk when you put data out there. There's risks of how it is picked up and used by others. I don't know what you can do about that, or even what guidelines can do about that $[\ldots]$ because the media can put a spin on it or whoever could pick it up and put a spin on it. Now that's the unfortunate side of things (LAHRC 3).

One recommendation voiced to us was that researchers should discuss, with community members, the process of dissemination and how harmful effects can be minimised prior to initiating the research.

[W]e had a med student here, I guess, a few years ago who had done some research on suicide rates in [a community], and he did a great job with it. And then his supervisor, at the end of it, wanted to publish it, but it hadn't gone through our ethics approval. And it came to light then [that the research had not been approved at the community level] at the time that they wanted to publish it. [H]e sort of came and wanted to put it through our Research Review Committee; but, at that time when we looked at it, the results - even though it was a good study and good results, it would probably identify the community, because we don't have that many communities and I think the specific community that he had researched and the numbers and, you have to really be cognizant of that; that they have small communities,

9 FAS refers to FASD, Fetal Alcohol Syndrome Disorder.

134/F. BRUNGER AND J. BULL 
and even though there's no names or anything in these research results, you can sometimes identify the community. [...] So, I don't think it ever got published because of that reason (LGH 1).

There is a concern that more prominence is given to research when it exoticises and studies Aboriginal communities for the benefit of outsiders than when it is done to improve the lives of individuals within Aboriginal communities. In particular, important health research is not being done in Aboriginal communities. Such research was reported to be not as prevalent in Labrador as other areas of inquiry, including social sciences and humanities research (folklore, literacy, history, genealogy, anthropology) and research in the natural sciences and engineering (climate change, environmental contaminants, natural resources). Aboriginal people in Canada experience a higher burden of illness than do non-Aboriginal populations. There are disparities in life expectancy, infant mortality, incidence of chronic diseases such as diabetes, arthritis, and cardiovascular diseases, and alcohol and substance abuse, suicide, and depression (Loppie Reading and Wein 2009). In Newfoundland and Labrador, it is clear from anecdotal accounts that suicide and FASD particularly require immediate and urgent attention. According to participants, while it is difficult to set research priorities for the good of society in general or Labrador Aboriginal communities in particular, there is an overwhelming need for immediate and applicable health and social services research.

\section{Whose agenda is it?}

[It has only been] in the last few years that [Aboriginal peoples of Labrador] are recognising how much of a benefit that might be to communities to be involved and to decide on what kind of research is happening in their community (LAHRC 1).

For community members who oversee research involving Aboriginal communities in Labrador, research ethics is all about the researchers' agenda - what is being studied, by whom, and why. Questioning the agenda is considered a key component of effective ethics review. Community-researcher partnerships, with the community as initiator, are thus an important way of gaining control over health research priorities.

So it's done the complete shift from the helicopter research to much more participatory; and I don't think we're where we need to be, which is [a situation in which] we [the community] would identify the [question to be researched] [...]. [O]ur goal obviously would be to be in a place where we would initiate our own research and go look for the partner, but that will be awhile coming because it's a capacity issue (NG 1).

To this end, there must also be new efforts to make researchers understand local needs and priorities. The community-researcher relationship should be one of mutual respect.

[T] here's an obligation [on] the community itself too, to let it be known what it wants researched (LMN1). 
[I]n Labrador we have an obligation to try and simplify things for researchers, if we're going to encourage researchers to come here. The communities and local organisations have a responsibility in the research process, and that does not mean the poor old researcher [is to be] dragged in and used to death by the community, because you get that too (LAHRC 1).

\section{Community consultation and consent}

Two important considerations were raised. First, community consultation and community consent should be clearly distinguished by communities and research ethics boards when advising researchers during the community review process. Second, community review of research should be clearly distinguished from ethics review of research, with the roles and responsibilities of each type of review clearly articulated and understood by community members, researchers, and research ethics boards.

Because of the complexity of the multiple and overlapping social and political group identities within Labrador, the governance of research in communities by communities is confusing. Who has the authority and legitimacy to represent the "community"? Such complexity can affect ethics review (e.g., Brunger 2006; Brunger and Weijer 2007; Burgess and Brunger 2000; Foster et al. 1998; Greely 1997; Kaufert et al. 1999, 2004; NAHO 2003; O’Neill 1998; Weijer 1999; Weijer et al. 1999). In cohesive communities with an appointed authority, the process may be straightforward. Researchers can collaborate with community leaders and elders to ensure that research goals are appropriate, harms and benefits explained and justifiable, and methods respectful toward that particular community. In these situations, where political authority is obvious and the community clearly bounded, everything may work well during the process of community consultation - in which the community and researcher together identify the potential harms and benefits of the proposed research and adjust the study design accordingly.

This model of "community consent" has been successful in many Aboriginal communities (Arbour and Cook 2006; Foster et al. 1998; Kaufert et al. 1999; Macaulay 1994). There has been development of a number of highly effective community consent contracts and ethics review processes and protocols. ${ }^{10}$ Examples include the Kahnawake Schools Diabetes Prevention Project Code of Ethics (KSDPP 2007) and the Guidelines for Ethical Aboriginal Research in the Manitoulin Area (Noojmowin Teg Health Centre 2003). Within Labrador, this model has been successfully employed by the Nunatsiavut Government, which has clearly defined the process of reviewing research on Nunatsiavut land, ${ }^{11}$ and by the NunatuKavut community, which has a similar process that goes directly through the NunatuKavut Community Council. ${ }^{12}$

10 It is important to note that community consent should not erode individual autonomy or the requirement for individual informed consent.

11 See contact information for the Inuit Research Advisor for Nunatsiavut Government at: http://www.naho.ca/inuit/research-and-ethics/research-permits-and-licences/.

12

See NunatuKavut Community Council, http://www.labradormetis.ca/home/96.

136/F. BRUNGER AND J. BULL 
This model faces practical challenges, however, in communities with complex lines of accountability and authority. Speaking on behalf of a group raises problems of representation and authority, given intra-group politics and power differentials, even within a relatively cohesive community. There may be coercion of individuals to participate by powerful community authorities and censorship of academically and socially important research by powerful political authorities (e.g., Burgess and Brunger 2000; Weijer 1999; Weijer et al. 1999). Importantly, if researchers seek consent from socially or culturally defined categories of the community (rather than politically defined ones), they may problematically reify these categories (Brunger 2006).

The challenges are even more complex in a "non-cohesive" community. ${ }^{13}$ For example, the Nunatsiavut government has no authority or jurisdiction over research with Labrador Inuit in the Labrador city of Happy Valley-Goose Bay. That city is home to Inuit as well as other Aboriginal peoples and non-Aboriginal people. Research is often conducted within the city and in ways that identify "being Inuit" as a variable or result of research, but no one Aboriginal group has the authority to review that research on behalf of the Inuit. Similarly, for the Innu communities and the NunatuKavut community of Labrador, where political authority does not necessarily correspond with geography, and where municipalities like Happy Valley-Goose Bay have multiple and overlapping "communities" of Aboriginal peoples, it is difficult to operationalise an ideal review process. For these communities, where no clear-cut authority can speak on behalf of a given group of Aboriginal peoples, or where the group itself is noncohesive and/or heterogeneous, one must make do with a process of community consultation followed by letters of support, rather than community review followed by consent. ${ }^{14}$

Community consultation and support is not sufficient to address the OCAP principles of "ownership, control, access, and possession" (see Schnarch 2004). Where lines of authority and accountability are clearly drawn, such control is ensured by the review process followed by consent (ideally in the form of a community-researcher agreement). For example, communities may keep registries of research to ensure that studies deemed "non-essential" to them are balanced with those that meet their immediate needs. They may put out "calls for proposals" to the university community indicating what types of research are currently welcomed as priority areas, or they may simply decline all non-essential or poorly negotiated research.

However, where communities are heterogeneous or non-cohesive (such as in Happy Valley-Goose Bay, as mentioned above), and where the process is one of community consultation accompanied by letters of support from key individuals, there is little or no leverage to control the research agenda. As long as letters of support are obtained, research can proceed even if not in the best interests of the community, not in

13 Burgess and Brunger (2000) have described the communities along continuums ranging from collective to aggregate, and from cohesive to non-cohesive.

14 The CIHR's (2008) Guidelines for Health Research Involving Aboriginal Peoples describes situations in which consultation and support, rather than review and consent, would be appropriate. 
line with its priorities, or likely to cause research fatigue and lack of participation in future studies more important to its needs.

\section{Conclusion}

Community review of research differs from the work of research ethics boards, such as the provincial Health Research Ethics Board (HREB). A Research Ethics Board (REB) is designed to consider ethical principles, including scientific validity, individual free and informed consent, respect for vulnerable persons, privacy and confidentiality, justice and inclusiveness in subject selection, and the balance of harms and benefits. These principles were developed to protect the research participants. While increasing attention is being paid to community or group considerations in research (e.g., TCPS2 includes a chapter on research involving Aboriginal peoples), REB principles tend to emphasise individuals, not groups.

Community review, by contrast, is fundamentally about the group. Its work encompasses a much broader purview, addressing questions such as: 1) Does the research fit with the priorities for research defined by our community? 2) Do we have the capacity to participate in this research at this time? 3) Does this research fit with our community values? And, finally, if those requirements are met, 4) Is the researchercommunity agreement fair in terms of benefit sharing, plans for conduct and dissemination, and all other elements of a rigorous community-based research agreement? ${ }^{15}$ Community review of research is, then, more akin to hospital-based reviews of research designed to examine whether the resources are in place. Community review committees should not merely replicate the work of an REB at the community level.

Under the provincial HREB, there is a clear definition of the policy on accountability between an ethics review and community review (or consultation, depending on the case), and this policy serves as a useful model for other communities and REBs. The HREB will not approve research involving Aboriginal peoples in Newfoundland and Labrador until there is clear evidence of community consultation, review, and approval. Where community authority exists, it will be in the form of a community-researcher agreement. Where no clear authority exists, evidence of community consultation and a letter of support will be needed. If the HREB receives no such documentation, it will not approve the proposed research.

It was clear from our discussions with key informants that, first, community leaders and elders need to be aware of their right to say "no" to researchers and, second, they need to understand and agree that the community has a responsibility to be available to researchers to negotiate, advise, and revise proposed research to ensure that good research can proceed in a timely fashion. The HREB needs to understand and

15 We do not list the elements of a good community-researcher agreement here, as a substantial literature addresses this subject (e.g., CIHR 2008).

138/F. BRUNGER AND J. BULL 
agree that the community review process is legitimate and thorough, and is the best way to determine whether research is appropriate for community values and needs.

Once the lines of accountability between community review committees and REBs are understood and respected, researchers can more easily navigate the system. For example, if research on diabetes is being proposed for one clearly definable NunatuKavut community with a rigorous system of review and approval, and for a second community of Inuit, NunatuKavut, Innu, and non-Aboriginal people with no obvious system of Aboriginal review and approval, then two separate processes will be at work. Research in the first community will follow a process of community consultation and review with an approved community-researcher agreement; research in the second community, however, will depend on consultation with a few key stakeholders (e.g., elders and community leaders) who will give advice on the project and provide a letter of support. The first community has the authority to say "no"; the second (mixed) community has no appointed authority and therefore cannot say no (although the researcher may end up with better recruitment and results by revising the proposal in line with the recommendations of those consulted).

We argue for the adoption and use of a consistent label for community review (Community Research Review Committee or CRRC), as distinct from ethics boards (REBs) to ensure that their different goals are understood and appreciated by all parties involved. The distinction between community review (and approval) and community consultation (and support) is key to understanding the lines of accountability and authority. We advocate a community review process, distinct from the "ethics" review of research ethics boards, that explicitly attends to research in the context of ongoing colonialism. Such a system places the research process in the hands of researchers in consultation with communities, with transparent and obvious lines of accountability, with appropriate oversight by research ethics review boards and, where the cohesiveness and homogeneity of the community permits, with community review committees. A good working relationship between communities and the REBs will ensure that the two distinct levels of review enable, rather than silence, good research.

\section{Acknowledgments}

The 2007 research "Interpreting the CIHR Guidelines for Health Research Involving Aboriginal Peoples in community-based research. Pilot Study" was supported by the Atlantic Aboriginal Health Research Program of the CIHR (Canadian Institutes of Health Research). We wish to thank the LAHRC (Labrador Aboriginal Health Research Committee) for their guidance, in particular, John Graham (Chair) and Darlene Wall (NunatuKavut Community Council). We are very appreciative of the very informative and helpful advice offered by the peer reviewers of this journal; we hope we have done justice to their comments. 


\section{References}

ALFRED, Taiaiake and Jeff CORNTASSEL

2005 Being Indigenous: Resurgences against Contemporary Colonialism, Government and Opposition, 40(4): 597-614.

ARBOUR, Laura and Doris COOK

2006 DNA on loan: Issues to consider when carrying out genetic research with aboriginal families and communities, Community Genetics, 9(3): 153-160.

BATTISTE, Marie (ed.)

$2000 \quad$ Reclaiming Indigenous Voice and Vision, Vancouver, UBC Press.

BIRD, Phillip

2002 Inuit Women's Traditional Knowledge Workshop on the Amauti and Intellectual Property Rights, Final report, Rankin Inlet, Nunavut, May 2427 2001, Ottawa, Pauktuutit Inuit Women's Association.

BRUNGER, Fern

2006 Discrimination génétique et éthique de la recherche: consentement et politique du risque, in M.-H. Parizeau (ed.), Néoracisme et dérives génétiques, Québec, Presses de l’Université Laval: 231-246.

BRUNGER, Fern and Charles WEIJER

2007 Politics, risk, and community in the ICBG-Chiapas case, in J.V. Lavery, E.R. Wahl, C. Grady, E.J. Emanuel (eds), Ethical Issues in International Biomedical Research: A Casebook, New York, Oxford University Press: $35-42$.

BULL, Julie

2008 Defining our Ethical Space: Labrador Innu, Inuit, and Inuit-Métis Perspectives on Governance of Health Research, Master's Thesis, University of Prince Edward Island, Charlottetown.

BURGESS, Michael and Fern BRUNGER

2000 Negotiating collective acceptability of health research, in Michael McDonald (ed.), The Governance of Health Research Involving Human Subjects (HRIHS), Ottawa, The Law Commission of Canada: 117-151.

CIHR (CANADIAN INSTITUTES OF HEALTH RESEARCH)

2008 Guidelines for Health Research Involving Aboriginal People, Ottawa, Canadian Institutes for Health Research (online at: http://www.chirirsc.gc.ca/e/29134.html). 
CIHR, NSERC and SSHRC (CANADIAN INSTITUTES OF HEALTH RESEARCH, NATURAL SCIENCES AND ENGINEERING RESEARCH COUNCIL OF CANADA and SOCIAL SCIENCES AND HUMANITIES RESEARCH COUNCIL OF CANADA)

2010 Tri-Council Policy Statement: Ethical Conduct For Research Involving Humans, December 2010.

CUNNINGHAM, Chris

2000 A framework for addressing Maori knowledge in research, science and technology, Pacific Health Dialog, 7(1): 62-69.

FOSTER, Morris W., Deborah BERNSTEN and Thomas H. CARTER

1998 A model agreement for genetic research in socially identifiable populations, American Journal of Human Genetics, 63(3): 696-702.

GOVERNMENT OF NEWFOUNDLAND AND LABRADOR

2007 Health Research Ethics Authority Act (online at: http://www.assembly.nl. $\mathrm{ca} /$ legislation/sr/statutes/h01-2.htm

GREELY, Henry T.

1997 The control of genetic research: Involving the "Groups Between", Houston Law Review, 33(5): 1397-1430.

HUMPHREY, Kim

2007 Dirty questions: Indigenous health and 'Western research', Australian and New Zealand Journal of Public Health, 25(3): 197-202.

KAUFERT, Joseph, Laura COMMANDA, Brenda ELIAS, Roda GREY, T. KUE YOUNG and Barney MASAZUMI

1999 Evolving participation of Aboriginal communities in health research ethics review: The impact of the Inuvik workshop, International Journal of Circumpolar Health, 58(2): 134-144.

KAUFERT, Joseph, Kathleen Cranley GLASS and William L. FREEMAN

2004 Background paper on issues of group, community, or First Nation consent in health research, Ottawa, The Canadian Institutes of Health Research.

\section{KSDPP (KAHNAWAKE SCHOOLS DIABETES PREVENTION PROJECT)}

2007 Kahnawake Schools Diabetes Prevention Project Code of Research Ethics (online at: http://www.ksdpp.org/elder/code_ethics.php).

LOPPIE READING, Charlotte and Fred WEIN

2009 Health Inequalities and Social Determinants of Aboriginal Peoples' Health, Ottawa, National Collaborating Centre for Aboriginal Health. 
MACAULAY, A.C.

1994 Ethics of research in native communities, Canadian Family Physician, 40:1888-1890.

NAHO (NATIONAL ABORIGINAL HEALTH ORGANIZATION)

2003 Ethics Tool Kit: Information to share from the First Nations Centre of the National Aboriginal Health Organization, Ottawa, First Nations Centre of the National Aboriginal Health Organization (online at: http://www.naho.ca/ documents/fnc/english/FNC_EthicsToolkit.pdf).

\section{NOOJMOWIN TEG HEALTH CENTRE}

2003 Guidelines for Ethical Aboriginal Research in the Manitoulin Area (online at: http://www.noojmowin-teg.ca/Shared\%20Documents/GEAR\%20-\%20 FINAL.pdf).

O'NEILL, P.

1998 Communities, collectivities, and the ethics of research, Canadian Journal of Community Mental Health, 17(2): 67-78.

SAID, Edward

1978 Orientalism, New York, Pantheon Books.

SMITH, Linda Tuhiwai

1999 Decolonizing Methodologies: Research and Indigenous Peoples, London, Zed Books.

SCHNARCH, Brian

2004 Ownership, Control, Access, and Possession (OCAP) or Self-Determination Applied to Research. A Critical Analysis of Contemporary First Nations Research and Some Options for First Nations Communities, Journal of Aboriginal Health, 1(1): 80-95.

\section{STATISTICS CANADA}

2006 Aboriginal Population Profile. 2006 Census, Ottawa, Statistics Canada (online at: http://www12.statcan.gc.ca/census-recensement/2006/dppd/prof/92-594/index.cfm?Lang=E).

WEIJER, Charles

1999 Protecting communities in research: Philosophical and pragmatic challenges, Cambridge Quarterly Health Care Ethics, 8(4): 501-513.

WEIJER, Charles, Gary GOLDSAND and Ezekiel J. EMANUEL

1999 Protecting communities in research: current guidelines and limits of extrapolation, Nature Genetics, 23(3): 275-280. 